Jurnal Iqra' Vol.3. No.1, Januari - Juni 2009

\title{
STAIN/IAIN MENUJU UIN \\ (Perspektif Pemikiran Pendidikan A. Malik Fadjar)
}

\author{
Oleh: Muh. Idris*
}

\begin{abstract}
Abstrak
STAIN/IAIN dalam konteks kekinian tidak memadai lagi dalam merspon tantangan globalisasi dan modernisasi. Islam yang begitu universal dalam pengembangan nilai-nilai keilmuan dan dapat mencapai titik puncak bangunan peradaban sejarah pada abad klasik khususnya pada masa pemerintahan al-Makmun pada masa itu. Islam berbicara persoalan puasa misalnya, hal ini dapat dimaknai bahwa Islam harus kita kembangkan pada ilmuilmu seputar kesehatan. Fiqih dapat dikembangkan dengan nilai-nilai keilmuan yang bermuara pada hukum-hukum sosial termasuk Isra' dan mi'raj dapat dikembangkan keilmuannya melalui sins dan teknologi, dan semacamnya. Dari informasi tersebut bahwa STAIN/IAIN suatu keharusan untuk menuju UIN dalam merespon tantangan globalisasi, otonomisasi dan modernisasi. UIN tidak mengenal fakultas agama yang ada adalah pengembangan kultur keilmuan yang bernuansa Islam yang rahmatan lil'alamin.
\end{abstract}

Kata Kunci: Sejarah singkat, tantangan menuju UIN dan STAIN/IAIN Menuju UIN

\section{Pendahuluan}

Pendidikan merupakan sebuah proses dan sekaligus sistem yang bermuara pada pencapaian tujuan. Diyakininya sebagai sesuatu yang ideal dan dapat merespon tantangan globalisasi saat ini. Maka pendidikan Islam di Indonesia sebagai sub sistem dari pendidikan nasional yang mencita-citakan terbentuknya insan kamil atau muslim paripurna, ${ }^{1}$ secara implisit akan mencerminkan ciri-ciri kualitas manusia Indonesia seutuhnya. ${ }^{2}$

Menurut A.Malik Fadjar bila ditelusuri perjalanan sejarah pendidikan Islam di Indonesia, diketahui bahwa pendidikan Islam berasal dari berbagai model dan bentuk antara lain madrasah dan sekolah yang merupakan pemaduan antara ilmu umum dan agama.

\footnotetext{
* Penulis adalah dosen tetap pada Jurusan Tarbiyah Program Studi Pendidikan Agama Islam STAIN Manado.

${ }^{1}$ Muhammad Idris, Pola Dasar Pembaruan Dalam Pemikiran Pendidikan A. Malik Fadjar, dalam Jurnal Iqra' Vol. 6-Desember 2008.

${ }^{2}$ A. Malik Fadjar, Holistika Pemikiran Pendidikan, (Jakarta, PT Raja Grafindo, 2005), h.275. Insan kamil A.Malik Fadjar dapat dipahami ketika integralnya sains (zikir) teknologi (fikir) dalam diri peserta didik. Dengan demikian peserta didik dapat berfikir rasional untuk menjadi penggerak masyarakat luas secara praksis.
} 


\section{Muh. Idris - STAIN/IAIN Menuju UIN......}

Dalam perkembangan global sekarang ini, pendekatan interdisipliner tidak bisa dielakkan lagi. Orang yang ingin bicara fikih diharuskan bisa bicara lingkungan dan aspek-aspek yang terkait dengan kehidupan sosial yang nyata. Hal ini bukan sekedar materi, tapi bagaimana mengasosiasikan, dan merefleksikan realitasnya. Orang menyoroti puasa dari segi kesehatan, harus paham ilmu kesehatan. Orang yang bicara zakat harus mengetahui ilmu ekonomi dan orang bicara isra' dan mi'raj harus mengetahui sains dan teknologi dan lain sebagainya.

Lebih lanjut A.Malik Fadjar menyatakan bahwa semuanya itu didesain dengan sains dan teknologi. Kalau IAIN/STAIN ingin tumbuh dan berkembang di tengah-tengah kehidupan global dengan mengandalkan ilmu agama saja tentu kemampuan pencernaannya kurang memadai. ${ }^{3}$ Dengan demikian pengembangan pendidikan Islam menuju unuversitas suatu keharusan guna merespon kemajuan modernisasi, otonomisasi, dan globalisasi.

Semangat A.Malik Fadjar ingin menjadikan pendidikan Islam itu kompetitif dan berkualitas sehingga tidak kalah bersaing dengan pendidikan umum. Oleh karena itu A.Malik Fadjar sangat mendukung perubahan IAIN menjadi UIN. Dia ingin menjadikan IAIN menjadi lembaga pendidikan modern dan berkualitas baik.

A.Malik Fadjar berpendapat bahwa pendidikan dalam makna yang luas pada hekekatnya menyangkut masa depan hidup dan kehidupan umat manusia dalam membangun peradaban. Di masa sekarang dan yang akan datang pengelolaan pendidikan harus lebih demokratis dalam bentuk memberikan otonomi seluas-luasnya kepada masyarakat. ${ }^{4}$

Bangsa Indonesia sangat merasakan pentingnya penguasaan ilmu dan teknologi demi pembangunan yang meliputi multi aspek dalam kehidupan bangsa. ${ }^{5}$ Sehingga perlu dilakukan islamisasi dalam upaya membangun kembali semangat umat Islam untuk mengembangkan ilmu pengetahuan melalui kebebasan penalaran intelektual dan kajiankajian rasional-empirik dan filosofis dengan tetap merujuk pada kandungan al-Qur'an dan Sunnah Nabi, sehingga umat Islam akan bangkit dan menyusul ketertinggalannya dari Barat. $^{6}$

Dalam era global seperti ini tantangan dan perkembangan sains dan teknologi semakin massif eskalasi pasar bebas antar negara dan bangsa yang semakin meningkat,

${ }^{3}$ Muhammad Idris, Visi dan Praksis A.Malik Fadjar Dalam Pengembangan Pendidikan Islam, Disertsi SPS UIN Jakarta 2008. Sains dan teknologi bukan barang baru sejak Nabi Muhammad Saw, melakukan isra' dan mi'raj dapat diasosiasikan telah mlakukan perjalanan melalui desain teknologi yang begitu cepat melalui cahaya (teknologi) untuk menerima perintah Allah demi kemaslahatan manusia di bumi

${ }^{4}$ http://www.dikda.\% ein.org /hal =6\& id=5. Tanggal 11 Mei 2007.

${ }^{5}$ Yusuf Amir Feisal, Reorientasi Pendidikan Islam, (Gema Insani Press, 1995), h.88

${ }^{6}$ Armai Arief, Reformulasi Pendidikan, (Jakarta: CRSD Press, 2005), h. 124 
iklim kompetisi dalam berbagai aspek semakin ketat, dan tuntutan demokrasi serta masalah hak asasi manusia merupakan tantangan yang harus direspon oleh pendidikan Islam. ${ }^{7}$

Oleh karena itu, pembaruan pendidikan harus segera dilakukan agar masyarakat secara luas, keluarga, sektor swasta, politisi dan unit-unit pemerintahan di semua tingkatan dapat memahami bahwa pendidikan merupakan human investmen. Hal itu harus dirancang dan dibiayai secara lebih memadai agar bangsa ini mampu tumbuh dan bersaing dengan bangsa lain seiring dengan pertumbuhan dan proses demokratisasi dalam berbagai sistem kehidupan di Indonesia. ${ }^{8}$ Tidak salah jika Fazlurrahman menyatakan bahwa setiap reformasi dan pembaharuan dalam Islam harus dimulai dengan pendidikan. ${ }^{9}$

\section{Sejarah singkat dan Tantangan menuju UIN}

Dalam sejarah perkembangan pendidikan di Indonesia bahwa perguruan tinggi yang secara resmi didirikan sejak $1960,{ }^{10}$ oleh tokoh moderat KH. Wahid Hasyim dimaksudkan sebagai wahana umat menempa ilmu pengetahuan yang lebih tinggi. Sebagai seorang tokoh muslim yang tidak diragukan kecendekiaannya, pengaruh Wahid Hasyim tidak hanya terlihat dalam pendirian IAIN di seluruh Indonesia. Tetapi, ia juga tokoh yang terlibat dalam merumuskan Pancasila sebagai dasar negara yang melindungi berbagai paham dan suku bangsa. Dari informasi tersebut dapat dipahami bahwa akselerasi berfikir para tokoh-tokoh Islam sangat cemerlang dan berillian guna memanjukan pendidikan di Indonesia.

IAIN/STAIN bukanlah bentuk kelembagaan final dalam perkembangan kelembagaan perguruan tinggi Islam di Indonesia. Pada awal sejarahnya, IAIN sendiri memiliki beberapa nama seperti PTAIN (Perguruan Tinggi Agama Islam Negeri) yang diambil dari Fakultas Agama Universitas Islam Indonesia (UII) Yogyakarta berdasarkan Peraturan Pemerintah No. 34 Tahun 1950. Ketika itu PTAIN memiliki jurusan Da'wah (kelak Ushuluddin), Qodlo (kelak menjadi Syari'ah), dan Pendidikan (Tarbiyah). Pada tanggal 26 September 1951 namatersebut berubah lagi menjadi Perguruan Tinggi Negeri (PTN). Enam tahun kemudian, 14 Agustus 195 7, di Jakarta berdiri pula Akademi Dinas Ilmu Agama (ADIA) berdasarkan Penetapan Menteri Agama Nomor 1 Tahun 1957..11

Kemudian, untuk memenuhi kebutuhan umat Islam terhadap pendidikan tinggi agama Islam, Peraturan Presiden Nomor 11 Tahun 1960 tentang pembentukan Institut Agama Islam Negeri (IAIN) dikeluarkan. Menurut dokumen ini, penggabungan PTAIN dan

\footnotetext{
${ }^{7}$ Muhammad Idris, "Reformasi Pendidikan Islam dalam Sistem Pendidikan Nasional", Jurnal Iqra, No. 2. Tahun 2007

${ }^{8}$ Suyanto, Dinamika Pendidikan Nasional,(Dalam Percaturan Dunia Global), (Jakarta: PSAP Muhammadiyah, 2006), h.61.

${ }^{9}$ Fazlurrahman, Islam, (Chicago: The University of Chicago Press, 1979), h. 260

${ }^{10}$ Jurnal Inovasi Pendidikan Tinggi Agama Islam, Perta, Vol. VII/No. 01/ 2004, Lihat pula Affandi Muchtar, Mamahami Perguruan Islam, Pelita, Mei 2003, Kemudian bandingkan pula Atho Munzhor tentang Sejarah Singkat IAIN,

${ }^{11}$ Jurnal Innovasi Pendidikan Tinggi Agama Islam, Perta, Vol. VII/No. 01/ 2004.
} 


\section{Muh. Idris - STAIN/IAIN Menuju UIN......}

ADIA menjadi Institut Agama Islam Negeri (IAIN) "Al-Jami'ah al-Islamiah al- Hukumiyah" yang berkedudukan di Yogyakarta menjadi kenyataan. Pada 24 Agustus 1960 nama IAIN kemudian diresmikan di Yogyakarta oleh K.H. Wahid Hasyim. Demikianlah perguruan tinggi Islam Indonesia terns berubah sebagai respons atas perkembangan masyarakat dan sekaligus menanamkan nilai-nilai agama pada setiap peserta didiknya. ${ }^{12}$

Dalam perjalanan panjang selama 49 tahun STAIN/ IAIN/ UIN di Indonesia ini telah banyak menghasilkan lulusan baik pada strata satu, begitu juga pada strata dua dan tiga. IAIN tumbuh dan berkembang sejak beberapa dasawarsa yang lalu, dan telah menunjukkan keberadaanya sebagai lembaga pendidikan tinggi. Hasilnya telah banyak alumninya yang berkiprah di tengah-tengah kehidupan bangsa dan negara. Hal tersebut dapat di lihat hasilnya misalnya, menjadi da'i, guru agama, pegawai, pemikir, hakim agama, bahkan politikus, dan lain sebagainya adalah merupakan profesi alumni PTAIN. ${ }^{13}$

Perubahan status IAIN/ STAIN menjadi UIN, menurut Menteri Agama Said Agil Husin Al-Munawwar pada waktu itu, membawa berbagai implikasi dan tantangan cukup besar. Karena itu, Menteri Agama menyerukan agar segera berusaha mengkaji dan mencari solusinya. Dibutuhkan perjuangan dari Mendiknas dan kerja keras para pejabat eselon I di lingkungan Depdiknas dan Depag dalam rangka mewujudkan sebuah lembaga akademik yang bercitra dan memiliki kepercayaan kuat dari masyarakat. ${ }^{14}$

Selain itu, perubahan ini dimaksudkan agar UIN bisa mengembangkan disiplin ilmuilmu lain yang bersifat universal tanpa terkungkung pada ilmu-ilmu keagamaan semata. Perubahan tersebut tentunya didukung dengan berubahan lebih awal dari sisi SDM, administrasi dan pendanaan dan pengembangan kelembagaan. ${ }^{15}$ Diharapkan UIN bisa memberikan wacana dan wawasan keberagamaan yang betul-betul membumi pada setiap bidang keilmuan.

Orientasi seperti inilah yang mesti dilakukan oleh UIN di masa depan untuk membangun ilmu pegetahuan yang berkeadaban (civilized) dengan memasukkan ilmuilmu keagamaan pada setiap bidang keilmuan. Wacana ini, meminjam istilah Ismail Raji AlFaruqi disebut "Islamisasi ilmu pengetahuan." Relevansi semua ini terlihat ketika melihat wacana keagamaan tidak menyentuh sisi empirik persoalan di masyarakat.

Respons masyarakat terhadap perubahan status STAIN/IAIN menjadi UIN cukup beragam. Sebagian mereka menilai positif karena mahasiswa UIN, nantinya, tidak hanya terdiri dari kalangan muslim santri (pesantren), tetapi juga kalangan muslim non-santri

12 Jurnal Innovasi Pendidikan Tinggi Agama Islam, Perta, Vol. VII/No. 01/ 2004, Bandingkan pula Muhammadiyah Amin, Makalah yang disampaikan pada kuliah umum STAIN Manado tanggal 30 Maret 2009.

${ }^{13}$ Muhammadiyah Amin, Makalah yang disampaikan pada kuliah umum STAIN Manado tanggal 30 Maret 2009

${ }^{14}$ Jurnal Innovasi Pendidikan Tinggi Agama Islam, Perta, Vol. VII/No. 01/ 2004.

${ }^{15}$ Muhammad Idris, Pemberdayaan Kualitas Umat Menuju Masyarakat Madani (Sebuah opsi memasuki masyarakat yang membebaskan) Tesis pada PPs. IAIN- Alauddin, 2008) 
baik yang belajar di SMU, SMK, maupun lainnya. UIN terbuka bagi berbagai elemen masyarakat. Ketika IAIN Syarif Hidayatullah berubah menjadi UIN membuka jurusan umum, terlihat antusiasme masyarakat sangat tinggi.

Pada sisi lain penilaian negatif juga muncul seiring dengan pembukaan jurusan umum tersebut. Penilaian tersebut terangkum dalam beberapa poin berikut ini.

Pertama, semakin terkikisnya studi-studi keislaman (Islamic studies). Hal ini terlihat dari keluhan dosen UIN Syarif Hidatullah Jakarta karena semakin kecilnya mahasiswa yang menekuni Islamic studies seperti filsafat Islam, pendidikan Islam, sejarah dan peradaban Islam, dan lainnya. Islamic studies merupakan ciri khas IAIN selama bertahun-tahun. la merupakan cikal bakal IAIN untuk mencetak kader-kader par excellent seperti Mukti Ali, Harun Nasution, Munawir Sjadzali, Nurcholish Madjid, dan lainnya. Menurutnya, minat mahasiswa terhadap Islamic studies karena studi-studi tersebut dianggap tidak menjanjikan masa depan. Sejalan dengan perkembangan zaman, peserta didik memilih jurusan-jurusan umum seperti ilmu ekonomi, ilmu sosial, ilmu teknik, ilmu pariwisata, dan lainnya.

Kedua, budaya mahasiswa UIN menjadi sangat beragam. Budaya tersebut tentu saja bersinggungan antara satu dengan lainnya karena akar tradisinya berbeda-beda seperti santri versus non-santri, anak desa versus anak kota. Bahkan, seluruh budaya ini kemudian didialektikakan dengan budaya modern yang notabene dibawa oleh negaranegara Barat. ${ }^{16}$ Dalam konteks inilah meminjam istilah para kiai pesantren UIN tak ubahnya rumah sakit yang harus memberikan obat terhadap berbagai penyakit umat. UIN harus menyediakan banyak dana untuk biaya pengobatan berbagai penyakit yang diderita pasien tersebut. Karena itu, UIN harus bisa mengantisipasi munculnya perilaku-perilaku mahasiswa yang tidak mencerminkan almaternya.

Bila STAIN/IAIN menuju UIN dalam merespon tantangan globalisasi, tampaknya memang sangat relevant mengingat era ini nampak dirasakan saat ini sangat kompetitif, global, dan seringkali penuh nuansa krisis dan keguncangan. Sehingga semua lembaga perlu mengaca diri, sejauhmana ia memiliki kesiapan (konsep, SDM, dan mental) dalam memasuki wilayah globalisasi, otonomisasi dan modernisasi.

\section{STAIN/IAIN Menuju Universitas}

Visi dan praksis A.Malik Fadjar dalam pengembangan STAIN/IAIN menuju UIN merupakan usaha mempertegas, mempertajam dan memperbaharui pendidikan Islam dalam hal melayani kebutuhan mendasar manusia. Sebab pendidikan berkaitan masa depan umat manusia yang sustainable yang selalu mengalami dinamika di era global. Gagasan perubahan STAIN/IAIN menjadi UIN yang diangankan A.Malik Fadjar bukan sekedar perubahan "papan nama", tetapi sebagai model "reintegrasi keilmuan" yang menunjuk kepada satu bentuk pengembangan, peningkatan dan pemantapan status akademik yang

${ }^{16}$ Jurnal Innovasi Pendidikan Tinggi Agama Islam, Perta, Vol. VII/No. 01/ 2004. 


\section{Muh. Idris - STAIN/IAIN Menuju UIN......}

lebih proporsional dan profesional. ${ }^{17}$ Gagasan tersebut, sejalan dengan semangat wider mandate (mandat diperluas) untuk memberikan wewenang kepada PTAI supaya bisa lebih moderen dan mandiri.

Lembaga pendidikan tinggi agama sudah harus mendapatkan wider mandate, ${ }^{18}$ sebagai respon atas tantangan-tantangan baru yang dihadapainya. Dengan mandat lebih luas ini, antara lain, IAIN secara praksis diharapkan mampu berpartisipasi dalam mengintegrasikan ilmu-ilmu normatif dengan ilmu-ilmu obyektif. ${ }^{19}$ Tujuan dari perluasan mandat ini adalah reproduksi manusia akademis yang siap pakai dalam menghadapi tantangan zaman yang penuh dinamika di era global.

A.Malik Fadjar menyatakan bahwa UIN ke depan dapat menjadi model sistem pendidikan Islam yang memiliki "kualitas tinggi" dibandingkan dengan PTN/PTS yang lain yang memiliki status, peran dan fungsi yang sama, di samping memiliki otonomi lebih luas

${ }^{17}$ A.Malik Fadjar, Holistika Pemikiran Pendidikan, h.37. Visi dan orientasi pendidikan Islam sebagai lembaga yang melestarikan nilai-nilai luhur dalam membangun peradaban manusia yang bermartabat dan memperbaiki penyimpangan yang diakibatkan oleh pengaruh era globalisasi tersebut. Dengan demikian pendidikan harus mempersiapkan sumber daya manusia yang besar dan mampu menerima, serta menyesuaikan dan mengembangkan arus perubahan yang terjadi dalam lingkungannya.

${ }^{18}$ Wider mandate merupakan "mandat yang diperluas" adalah istilah yang dikembangkan oleh Departemen Agama dan Departemen Pendidikan Nasional untuk menyatakan pemberian kewenangan yang diperluas bagi STAIN/IAIN guna mengembangkan institusinya. Hal tersebut merupakan strategi awal, sekaligus program strategis jangka panjang, sebagai upaya IAIN mentransformasikan lembaganya menjadi UIN. Penting diketahui pada proses sejarahnya bahwa "Konsep IAIN Wider Mandate ini mulai dipopulerkan dan di laksanakan pada masa Azyumardi Azra, sebagai Rektor IAIN Syarif Hidayatullah Jakarta. Seperti Teknik Informatika, Agrobisnis, Manajemen, Ekonomi, dan Psikologi yang secara keseluruhan telah mengacu pada kurikulum Diknas. Namun demikian, upaya melakukan perubahan IAIN menjadi UIN dalam prakteknya bukanlah pekerjaan yang mudah. Di samping harus adanya kemauan yang keras, kesungguhan, serta kemampuan yang dimiliki oleh para pimpinan dan pengelola IAIN saat ini, juga harus dipertimbangkan tentang kemampuan mengelola, meningkatkan dan mengembangkannya secara berkesinambungan. Hal ini perlu ditegaskan karena beban yang harus dipikul dan permasalahan yang harus diatasi juga akan semakin berat, besar dan kompleks. Namun kini kaki sudah dilangkahkan, layar sudah dikembangkan, dan gendarang UIN sudah dipukul. Tidak ada alternatif lain kecuali terus mewujudkannya. Berbagai upaya ke arah itu sedang dilakukan secara intensif. Orang-orang yang mengkhawatirkan atas terjadinya penghapusan atau penciutan Fakultas-fakultas Agama yang diakibatkan oleh perubahan IAIN menjadi UIN tersebut sudah dicarikan jawabannya. Lihat Abuddin Nata, Manajemen Pendidikan; Mengatasi Kelemahan Pendidikan Islam di Indonesia, (Jakarta: Prenada Media, 2003), h.73-75. Lihat Pula Amril Mansur, dkk, Paradigma Baru; Reformulasi Pendidikan Tinggi Islam, h.109

${ }^{19}$ Fachry Ali, Kontinuitas dan Perubahan: Catatan Sejarah Social Budaya Alumni IAIN dalam Problem dan Prospek IAIN, (Jakarta: Ditbinperta, 2000), h. 371 
baik dalam pengembangan akademik, manajemen maupun admistrasinya. ${ }^{20}$ Dengan penataan elemen-elemen lembaga pendidikan secara menyeluruh didesain dengan teknologi yang maju maka lembaga pendidikan Islam akan mampu memenuhi logika persaingan pasar ke depan.

Sejalan dengan itu Azyumardi Azra menyatakan bahwa pengembangan IAIN menjadi UIN bertitik tolak dari beberapa hal yaitu: Pertama; IAIN belum berperan secara optimal dalam dunia akademik, birokrasi, dan masyarakat Indonesia secara keseluruhan. Di antara ketiga lingkungan ini, kelihatannya peran IAIN lebih besar pada masyarakat, karena kuatnya orientasi kepada dakwah daripada kepada pengembangan ilmu pengetahuan. Kedua, kurikulum IAIN belum mampu merespon perkembangan iptek dan perubahan masyarakat yang semakin kompleks, karena lebih berkonsentrasi pada pengembangan dan penguatan imtak. Hal ini disebabkan terutama karena bidang kajian agama yang merupakan spesialiasi IAIN kurang mengalami interaksi dan rapprochement dengan ilmu-ilmu umum, bahkan masih cenderung dikotomis. ${ }^{21}$ Kurikulum IAIN masih menitikberatkan pada ilmu-ilmu yang bersifat normatif; sedangkan ilmu-ilmu umum yang dapat mengarahkan mahasiswa kepada cara berpikir dan pendekatan yang lebih empiris dan kontekstual tampaknya masih belum memadai.

Oleh karena itu dapat diketahui bahwa transformasi IAIN ke UIN bermuara pada integrasi keilmuan dalam sebuah institusi pendidikan. Hal tersebut bisa dilihat dari dua dimensi, yang pertama adalah dimensi teologis, sedangkan yang kedua adalah dimensi modernisme sejarah.

Pertama, dimensi teologis. Betapa banyak ayat-ayat al-Qur'an menyeru kepada keseimbangan keadaan (balanced condition) antara kepentingan duniawi dan kepentingan ukhrawi. Prinsip Islam dalam hal ini adalah apa yang disebut dengan Islam kaffah (Islam yang dapat memeberikan inspirasi dan manfaat secara menyeluruh/universal). Sehingga kita akan menyadari bahwa ayat-ayat al-Qur'an yang menyangkut berbagai aspek dan dimensi

20 A.Malik Fadjar, Holistika Pemikiran Pendidikan, h.37. Dalam era globalisasi industrialisasi, peran pendidikan tidak terfokus pada penyiapan sumber daya manusia yang siap pakai mengingat kecenderungan yang terjadi dalam dunia kerja sangat cepat berubah dalam era ini. Sebaliknya, pendidikan harus mempersiapkan sumber daya manusia yang adaptif, mampu menerima, serta mampu menyesuaikan dan mengembangkan arus perubahan yang terjadi dalam lingkungannya.

${ }^{21}$ Azyumardi Azra, "Model Perubahan IAIN Alauddin Menjadi UIN; Sebuah Tawaran Berdasarkan Pengalaman UIN Jakarta" dalam Hadi D. Mapuna dkk. (Ed.), Dulu IAIN Kini UIN Alauddin, (Makassar: Alauddin Press, 2005), h. 82-83. Pendidikan merupakan usaha kemanusiaan yang dilakukan secara sadar dan rasional pencapaian cita-cita kemanusiaan yang tak pernah selesai dan tidak dapat dicapai oleh hanya satu generasi belaka. Selanjutnya ketika manusia kemudian menyadari bahwa cita-cita dan harapan manusia jauh melampui batas-batas usia manusia sendiri bahkan batas generasi dan zamannya, maka pendidikan dan rekayasa generasi masa-depan mulai dikembangkan dan dikonsep sebagai usaha sadar yang tak pernah berakhir. Oleh karena itu secara sistematis setiap usaha pendidikan merupakan bagian integral dari sebuah rekayasa sejarah. 


\section{Muh. Idris - STAIN/IAIN Menuju UIN......}

ilmu merupakan sabda-sabda Tuhan yang diturunkan kepada umat manusia. Prinsip universal dalam memahami Islam akan membawa kita kepada keyakinan bahwa ilmu umum-pun sebenarnya Islam, tanpa kita harus menjadi paranoid terhadap kesekuleran sebuah ilmu. Bisa saja pengembangan fakultas-fakultas umum dengan berbagai disiplin ilmu tersebut ditelaah akar pendukungnya dari pesan-pesan agama sehingga pendalaman ilmu-ilmu umum justru akan semakin mengokohkan keyakinan terhadap pemahaman terhadap agama. Di sinilah dimensi teoritis keagamaan menemukan dimensi praksis dan praktis untuk menuju otonomi dan meninggalkan dikotomi dalam dunia keilmuan.

Kedua, dimensi modernisme sejarah. Dalam konteks sejarah, kita mencatat masa keemasan Islam pada Abad Pertengahan di mana Islam mencapai puncak kejayaannya di lapangan ilmu pengetahuan. Pada masa itu muncul pakar-pakar Muslim di berbagai lapangan pengetahuan, seperti AI-Kindi (801-837), Al-Farabi (W.950), dan Ibn Maskawaih (W.1030) yang menggeluti lapangan filsafat; Ibn Sina (980-1037) dan Ibn Bajah (11601138) ahli di bidang kedokteran, Jabir ibn Hayyan (720-815) dan Al-Khawarizmi (780-850) yang masing-masing merupakan ahli kimia dan matematika, serta Al-Thabari (839-922) ahli dalam bidang sejarah dan hukum. Mereka hanyalah contoh kecil dari berbagai tokoh Abad Pertengahan. ${ }^{22}$

Dalam perspektif historis, jelas bahwa bangunan pengetahuan Islam pada saat itu dibangun dengan sangat integratif, dan kenyataannya ilmu pengetahuan umum dapat berkembang pesat bahkan melahirkan banyak pakar dalam berbagai disiplin ilmu. Sayangnya, gagasan besar yang agung tidak dilanjutkan oleh umat Islam malah cenderung menutup diri dari ilmu-ilmu umum dan mematikan kreatifitas nalar dan logika. Untuk itu transformasi IAIN ke UIN menuju otonomi dan meninggalkan dikotomi merupakan keharusan di era globalisasi yang penuh kompetitif.

Pemikiran A.Malik Fadjar dalam pengembangan pendidikan menuju universitas merupakan langkah stretegis dan futuristik, guna menata pranata-pranata sosial dari berbagai aspek dalam mengakomodasi perubahan-perubahan peradaban di era globalisasi.

Menurut Sofyan Effendi kebijakan A.Malik Fadjar dalam dunia pendidikan Islam dengan membuka STAIN dan IAIN menuju Universitas secara praksis tidak bertentangan

${ }^{22}$ Suwito dan Suprapto, "IAIN Menjadi Universitas?", dalam Mimbar Agama dan Budaya, Vol. XVIII, No.2, 2001, 160-161. Kualitas sumber daya manusia tidak hanya dapat diukur relevansinya secara internal yaitu berdasarkan kecocokan kualitasnya dengan sistem pendidikan tetapi juga harus memungkinkan kualitas tersebut dapat diukur relevansinya secara eksternal yaitu sesuai atau tidak dengan kebutuhan masyarakat, dalam dunia ekonomi, industri, budaya, maupun yang lainnya. Dan yang tidak kurang pentingnya, relevansinya dapat diukur dengan kesanggupannya untuk bersaing secara internasional. Kemajuan tidak hanya diukur oleh kemampuannya berswasembada, tetapi juga diukur oleh kemampuannya untuk mempertahankan diri, mengimbangi, bahkan mengalahkan kekuatan yang datang dari luar, khususnya yang berhubungan dengan kegiatankegiatan yang mengembangkan kemakmuran masyarakat dan kemampuan berkompetisi sebagai bangsa di hadapan bangsa-bangsa lain. 
dengan aturan, tidak ada larangan perguruan tinggi yang berada di bawah departemen menjadi lembaga pendidikan kedinasan. Jadi tidak melanggar dari aturan tapi aturan yang tertinggal dari kenyataan. ${ }^{23}$

Menurut A.Malik Fadjar, secara praksis UIN merupakan model sintesis antara pesantren dan perguruan tinggi. Tak bisa disalahkan bila UIN, selain mengembangkan aspek-aspek keilmuan dan profesionalisme, di dalamnya dikembangkan pula "ritual-ritual" pesantren, seperti khataman, tadarus al-Qur'an, dan bahkan hafalan al-Qur'an sebagaimana dikembangkan oleh UIN Malang. Mahasiswa yang hafal al-Qur'an bukan saja dari fakultasfakultas agama, tetapi meluas ke berbagai cabang fakultas, jurusan, dan program studi (umum). ${ }^{24}$

Sejalan dengan gagasan tersebut, Amin Abdullah menyatakan bahwa pemikiran inilah yang mendorong adanya gagasan tentang pengembangan IAIN sebagai pilot project menjadi Universitas Islam Negeri (UIN), di bawah Departemen Agama Republik Indonesia yang mencakup bukan hanya fakultas-fakultas agama, tetapi juga fakultas-fakultas umum dengan corak epistemologi keilmuan dan etika moral keagamaan yang integralistik. Dalam konsep ini fakultas-fakultas agama ${ }^{25}$ tetap dipertahankan seperti yang ada sekarang, namun perlu dikembangkan kurikulumnya yang sesuai dengan kebutuhan masyarakat pengguna jasa IAIN di era global dan diperkuat tenaga pengajar dan dosen-dosennya dengan berbagai metode dan pendekatan baru dalam islamic studies, humanities, dan ilmu-ilmu sosial, sedangkan dalam fakultas-fakultas umum, baik dalam bentuk wider mandate maupun universitas perlu dibekali muatan-muatan spiritualitas dan moral keagamaan yang lebih kritis dan terarah dalam format integrated curriculum, dan bukannya separated curriculum seperti yang berjalan selama ini. ${ }^{26}$

23 Muhammad Idris, Visi dan Praksis A.Malik Fadjar Dalam Pengembangan Pendidikan Islam, Disertsi SPS UIN Jakarta 2008.

${ }^{24}$ A.Malik Fadjar, Holistika Pemikiran Pendidikan, h.42. Semangat corak pendidikan yang diinginkan oleh Islam ialah pendidikan yang mampu membentuk "manusia yang unggul secara intelektual, kaya dalam amal serta anggun dalam moral dan kebijakan". Untuk meraih tujuan ini diperlukan-suatu landasan filosofis pendidikan yang sepenuhnya berangkat dari cita-cita Al-Qur'an tentang manusia. Sehingga pendidikan Islam harus dinamis dan menjadi obor dalam berpacu dan menghadapi perubahan social. Konservasi budaya yang selektif mengharuskan pendidikan untuk menumbuhkan pemahaman yang benar tentang kebutuhan dan tantangan masa depan manusia.

25 Amin Abdullah, Islamic Studies di Perguruan Tinggi; Pendekatan IntegratifInterkonnektif, (Yogyakarta: Pustaka Pelajar, 2006), h. 98. Fakultas agama bukan tradisinya tapi semangat nilai keberagamaan yang tetap dipertahankan dan dilanggengkan dalam program sehingga akan terjadi dinamika dalam pengembangannya.

26 Amin Abdullah, Islamic Studies di Perguruan Tinggi; Pendekatan IntegratifInterkonnektif, h. 98. Lihat pula Bambang Hidayat, Mozaik Pemikiran Sejarah dan Sains untuk Masa Depan, (Jakarta: PT. Kiblat, 2004), h.196. Titik sentralnya ialah manusia yang mampu merebut atribut budaya melalui pengetahuan dan teknologi. Karena, walaupun belum secara eksplisit dinyatakan, kita dapat mengindera bahwa manusia yang siap di bidang itulah kelak akan mampu 


\section{Muh. Idris - STAIN/IAIN Menuju UIN......}

Pengembangan IAIN ini diharapkan melahirkan pendidikan Islam yang ideal di masa depan. Program reintegrasi epistemologi keilmuan dan implikasinya dalam proses belajar mengajar secara akademik pada gilirannya akan menghilangkan dikotomi antara ilmu-ilmu umum dan ilmu-ilmu agama seperti yang telah berjalan selama ini.

Menurut A.Syafii Maarif, corak orientasi keilmuan yang dikembangkan IAIN beserta kualitas para pengampunya. Para pengampu yang kualifaid adalah mereka yang mampu memancing potensi intelektual para mahasiswanya agar terpikat oleh masalahmasalah besar, ${ }^{27}$ yang dihadapi Islam secara universal di abad ini. Sebab sebuah prodak keilmuan sangat ditentukan nilai kualitas pelayanan sesorang dan jaringannya compatible dengan kebutuhan masyarakat. ${ }^{28}$

Menurut Azyumardi Azra perubahan institut menjadi universitas harus dimulai dengan pengembangan SDM, khususnya pengadaan dosen dalam bidang-bidang yang akan dikembangkan sesuai dengan kebutuhan pasar. $^{29}$

Perubahan dan perkembangan ini bukan sekedar asal berkembang dan berubah. Diperlukan konsep yang matang dan detail, sehingga tidak mengulangi eksperimen dan pengalaman sejarah yang dilakukan oleh perguruan-perguruan tinggi umum dan agama yang didirikan oleh negara maupun swasta. Pengembangan ini berada dalam kerangka dan semangat harmonisasi keilmuan yang lebih universal, ${ }^{30}$ guna merespons perkembangan masa depan.

Dengan berubahnya IAIN Jakarta menjadi UIN, ${ }^{31}$ misalnya merupakan langkah

menolong masyarakatnya melepaskan diri dari kaitan-kaitan primordial dan berguna untuk masyarakat luas ke depan.

${ }^{27}$ A.Syafii Maarif, Peta Bumi Intelektualisme Islam di Indonesia, (Bandung: Mizan, 1993), h. 153

${ }^{28}$ Charles Hoy. Et.al., Improving Quality in Education, (New York: Falmer Press, 1999), h.2 Bandingkan Pula, Bryan Wilson, Religion in Sociologi Perspective, (New York: Oxpord University Press, 1982), h. 6

${ }^{29}$ Azyumardi Azra, Islam Subtantif: Agar Umat Tidak Jadi Buih, (Bandung: Mizan, 2000), h. 422

${ }^{30}$ T.S. Sodhi, A. Tex Book of Comparative Education Philosophy, Patterns and Problems of Nasional Systems, (Delhi: Vikas Publishing, 1983), h.77. Lihat pula, Clark Kerr, The Uses of the University, (New York: Harvard University Press, 1964), h. 47

${ }^{31}$ Perubahan IAIN dari institut menjadi universitas bukanlah perubahan tanpa rencana, ia merupakan rencana strategic karena adanya berbagai tantangan ke depan dan berkait erat dengan tujuan strategi nasional pendidikan tinggi yang menjadi acuan bagi pengembangan organisasi IAIN. Adapun tantangan dan masalah yang dihadapi IAIN/STAIN, antara lain : 1.Pengembangan IAIN Jakarta dan IAIN Yogyakarta sebagai "IAIN Pembina" yang bertugas membina dan mengembangkan IAIN dan STAIN lainnya. Kedua IAIN ini akan dikembangkan dengan konsep dasar "IAIN dengan mandat yang lebih luas" (wider mandate). Dengan konsep ini, IAIN lebih lues tidak hanya dalam bidang agama, melainkan juga dalam bidang-bidang ilmu humaniora, dan ilmu-ilmu alam/eksakta. Dengan mandat yang lebih luas ini, maka upaya untuk mengintegrasikan "Ilmu agama" dan "Ilmu 
dinamis untuk "membangun sistem pendidikan yang integralistik dan komprehensif dalam berbagai disiplin ilmu dalam rangka memenuhi tuntutan dan kebutuhan masyarakat terhadap lembaga pendidikan tinggi yang mampu menghasilkan intelektual yang profesional dan bermoral". ${ }^{32}$

Dari berbagai latar belakang dan tujuan tersebut, terlihat bahwa ide perubahan lembaga PTAI bersumber dari perenungan internal dan eksternal tentang posisi dan fungsi yang selama ini dijalani oleh IAIN serta respons terhadap realitas yang berkembang dalam masyarakat. ${ }^{33}$ Perenungan internal telah merevisi cara pandang IAIN dan Departemen Agama tentang konstruksi keilmuan yang "sesungguhnya" yang bersifat non-dikotomis. Sedangkan perenungan eksternal telah "membuka mata" mereka tentang kebutuhankebutuhan yang berkembang di masyarakat sehingga perlu disikapi secara kongkrit. Perenungan seperti ini telah membawa perubahan mental akademik yang sejajar dengan dengan lembaga-lembaga pendidikan lain dan menyatukan ilmu yang terkesan dikotomi menuju otonomi sehingga akan melahirkan wawasan keilmuan yang lebih luas dan lues.

UIN yang dicita-citakan sebagai center of exellence bagi pengembangan keilmuan pada umumnya dan keilmuan Islam pada khususnya, sehingga terbentuk komunitas ilmiahreligius (religious-scientific community) yang bersendikan ajaran agama. Bukan sekadar pengawal, penjaga, dan pelestari tradisi yang ada. UIN diharapkan tidak saja piawai sebagai pencetak 'guru agama' dan kiai tradisional, melainkan bagaimana bisa melahirkan kiai-kiai profesional di dalam mengurus pesantren perikanan, pesantren peternakan, pesantren perkebunan, pesantren pertambangan, pesantren perindustrian, dan sebagainya. Tentu dengan pengejawantahan secara profesional di setiap bidang akademik yang dibuka. ${ }^{34}$

Apa yang digagas oleh A.Malik Fadjar, secara praksis bahwa pengembangan STAIN/IAIN menuju UIN kiranya merupakan langkah strategis dan futuristik. Melalui pengembangan STAIN/IAIN menuju UIN ini A.Malik Fadjar meyakini bahwa umat Islam bisa bermain dan memainkan peran yang sesungguhnya di dalam pergaulan global. Memaknai ini, A.Malik Fadjar mengemukakan: bahwa masa depan harus dijemput dimana

umum" dapat direalisasikan. 2.Peningkatan otonomi IAIN. Dengan otonomi yang lebih besar, IAIN dapat mengembangkan dirinya secara lebih maksimal, baik dalam bidang ilmiah akademik maupun dalam manajemen dan keuangan. 3.Peningkatan akuntabilitas IAIN dari segi kelembagaan dan akademis, sehingga kelembagaan IAIN lebih kokoh dan alumninya juga lebih maju, baik dalam ilmu agama (yang menjadi basic-nya) maupun dalam ilmu umum, serta keahlian dan keterampilannya. 4.Peningkatan kerja sama dengan perguruan tinggi lainnya baik di dalam maupun di luar negeri, guna menciptakan sinergi yang dapat mendorong akselarasi peningkatan mutu pendidikan di IAIN. Lihat Muhyi Batubara, Sosiologi Pendidikan, (Jakarta: Ciputat Press, 2004), h. 29

${ }^{32}$ IAIN Syarif Hidayatullah, Proposal konversi IAIN Menjadi Universitas Islam Negeri (UIN) Syarif Hidayatullah Jakarta, Jakarta, 2000. h. 5

${ }^{33}$ Suwito dan Suparto, "IAIN Menjadi Universitas", Dalam Mimbar Agama dan Budaya, Vol.XVIII,No.2, 2000, h. 155

${ }^{34}$ Imam Tholkhah dan Ahmad Barizi, Membuka Jendela Pendidikan: Mengurai Akar Tradisi dan Integrasi Keilmuan Pendidikan Islam, h . 108 


\section{Muh. Idris - STAIN/IAIN Menuju UIN......}

sarananya adalah pendidikan. Oleh karena itu pendidikan harus dipacu ke arah masa depan manusia. Di sinilah sesungguhnya makna pentingnya secara terus-menerus memperbarui sistem pendidikan kita. Ungkapan life long education, sejatinya sudah disuguhkan oleh Nabi Saw. ketika menyuruh para sahabat belajar ilmu ke Cina (uthlub al-'ilm wa law bi al-shîn) yang artinya carilah ilmu walau sampai ke negeri Cina (hadis) dan mencari ilmu sejak lahir sampai mati (uthlub al-'ilm min al-mahdi ila al-lahd) yang artinya carilah ilmu sejak dari buaian sampai engkau meninggal dunia (hadis). Untuk itu, manusia harus senantiasa belajar dan belajar (learn how to learn). Belajar itu merupakan rekreasi ke arah masa depan. ${ }^{35}$

Menurut A.Malik Fadjar kalau kita menelusuri perjalanan sejarah pendidikan Islam di Indonesia, dapat diketahui bahwa pendidikan Islam berasal dari berbagai model dan bentuk antara lain madrasah dan sekolah yang merupakan pemaduan antara ilmu umum dan agama. ${ }^{36}$ Dalam perkembangan global sekarang ini, pendekatan interdisipleiner tidak bisa dielakkan lagi. Orang yang ingin bicara fikih diharuskan bicara lingkungan dan aspek-aspek yang terkait dengan kehidupan nyata. Hal itu bukan sekedar materi, tapi bagaimana mengasosiasikan, merefleksikan realitasnya. Orang menyoroti puasa dari segi kesehatan, harus paham ilmu kesehatan. Orang yang bicara zakat harus mengetahui ekonomi dan lain sebagainya.Semuanya itu didesain dengan ilmu pengetahuan dan teknologi. Kalau IAIN ingin tumbuh dan berkembang ditengah-tengah kehidupan global mengandalkan ilmu agama saja tentu kemampuan pencernaannya kurang memadai. Oleh karena itu Mukti Ali dan Munawir Sjadzali mengirim mahasiswa studi ke Barat. Dengan terbentuknya UIN diharapkan berbagai disiplin ilmu saling bersinergi dan saling berkembang di sini. Dokter keluaran UIN berbeda dengan UI misalnya dengan dikembangkan nilai pendekanpendekatan yang Islami. Artinya alumni UIN dapat menjelaskan dan menerapkan pemahaman ayat-ayat al-Qur'an dan sunnah dalam anatomi tubuh manusia.

Gagasan strategi pengembangan pendidikan agama dan keagamaan (melalui STAIN dan UIN) ini bagi A.Malik Fadjar merupakan kebutuhan yang terus-menerus harus diusahakan. Usaha memecahkan persoalan pendidikan dan menjawab tantangan kehidupan pun harus dilakukan dengan memperluas komunikasi dan konsultasi akademik ke berbagai disiplin keilmuan; seperti filsafat, sejarah, bahasa, agama, antropologi, sosiologi, ekonormi, politik, biologi, informatika, dan manajemen (sebagai kunci keberhasilan diri dan sosial). A.Malik Fadjar mengungkap bahwa mendekati ajaran-ajaran agama dan keagamaan dewasa ini memerlukan perangkat ilmu-ilmu lain, seperti sosiologi, antropologi, dan arkeologi.

${ }^{35}$ A.Malik Fadjar, Holistika Pemikiran Pendidikan, h.38. Manusia yang produktif adalah manusia yang memiliki ciri-ciri dasar: percaya kepada dirinya sendiri sebagai akibat dari kesediaan serta kemampuannya untuk menerima seluruh keadaan dirinya secara (ikhlas)), mencintai lingkungannya, memahami persoalan dan kebutuhan zamannya, dan dapat bekerja berdasarkan metode tertentu.

36 Muhammad Idris, Visi dan Praksis A.Malik Fadjar Dalam Pengembangan Pendidikan Islam, Disertsi SPS UIN Jakarta 2008. 
Tentu suatu arah pengembangan masyarakat profesionalisme dalam konteks pengelolaan fisik-material, sosial, dan etik. ${ }^{37}$

Sementara itu Muhadjir Effendy berpendapat bahwa A.Malik Fadjar ingin melakukan integrasi keilmuan antara agama, sains dan teknologi dalam satu institusi. Di lain sisi A.Malik Fadjar tidak terlalu suka hal-hal yang normatif apa lagi yang membelenggu kebebasan individu. A.Malik Fadjar sangat menyenangi pembaruan-pembaruan dalam dunia pendidikan Islam dan berani mengambil resiko. ${ }^{38}$

Hal yang sama juga diungkapkan oleh Tarmizi Taher bahwa kekhasan pemikiran A.Malik Fadjar yaitu kombinasi ilmu agama, sains dan teknologi, sesuai pengalaman pendidikannya dari IAIN Malang hingga ke Barat. Pemikirannya ini diwarnai oleh organisasi Muhammadiyah yang merupakan salah satu gerakan pembaharuan di Indonesia. Pembaharuan pemikiran inilah yang menjadi semangat dalam dunia pendidikan yang cirinya sekolah umum.

Sementara itu menurut Sofyan Effendi bahwa semangat A.Malik Fadjar dalam pengembangan pendidikan adalah islamic studies, yaitu dikaji dengan pendekatan moderen yang didukung dengan berbagai aspek ilmu. Gaya dan semangat identik dengan Mukti Ali.

Terkait dengan integrasi ilmu ini, Mulyadhi Kartanegara menyatakan bahwa dasar dari integrasi ilmu dalam Islam adalah konsep tauhid. Konsep tauhid diambil dari formula konfesional Islam "Lâ Ilâha Illâ Allâh" yang artinya tidak ada Tuhan melainkan Allah, telah menjadi prinsip dan ajaran paling dasar dari ajaran Islam, dan dalam kaitannya dengan integrasi Ilmu telah menjadi prinsip yang paling utama dari prinsip-prinsip epistemologi Islam, sehingga ia juga telah menjadi asas pemersatu atau dasar integrasi ilmu pengetahuan manusia. ${ }^{39}$

Basis integrasi ilmu-ilmu agama dan umum, tentu saja ilmuwan-ilmuwan muslim akan akan percaya sepenuhnya bahwa sumber dari segala ilmu adalah Allah, Tuhan yang sering mereka sebut Sang Kebenaran (al- $\underline{H} a q q)$ atau ada juga yang menyebutnya dengan ultimate reality (relitas sejati). Dan karena tujuan ilmu adalah untuk mengetahui sesuatu sebagaimana adanya, yang berarti untuk mengetahui kebenaran sejati, maka Tuhan sebagai kebenaran sejati tentu merupakan sumber bagi segala kebenaran-kebenaran lainnya, termasuk kebenaran atau realitas-realitas ilmu.

Hal yang sama juga dikemukakan oleh Husni Rahim yang menyatakan bahwa dalam Islam tidak dikenal dikotomi antara agama dan ilmu pengetahuan. Pandangan ini

${ }^{37}$ A.Malik Fadjar, Holistika Pemikiran Pendidikan, h. 39. Dengan keyakinan seperti di atas, pendidikan Islam telah menempati posisi yang sangat central dalam kehidupan manusia dan sejalan pula dengan cita-cita pendidikan. Dan melalui cara tersebut dapat pula terjamin kelangsungan hidup manusia secara lebih bahagia, damai dan sejahtera baik untuk dunia maupun bagi akhirat.

${ }^{38}$ Muhammad Idris, Visi dan Praksis A.Malik Fadjar Dalam Pengembangan Pendidikan Islam, Disertsi SPS UIN Jakarta 2008.

${ }^{39}$ Mulyadhi Kartanegara, Integrasi Ilmu dalam Perspektif Filsafat Islam, (Jakarta: UIN Jakarta Press, 2003), h. 12 


\section{Muh. Idris - STAIN/IAIN Menuju UIN......}

mengacu pada keyakinan Islam yang paling utama yaitu tauhid. Ilmu pengetahuan dalam pandangan Islam pada hakekatnya milik Allah dan manusia hanya mampu menguasainya dengan terbatas. Sebagai hamba yang berada di alam syahâdah (nyata), manusia dapat memiliki pengetahuan disebabkan kekuatan nalar yang diberikan Allah kepadanya. Dengan demikian terdapat hubungan antara pandangan dunia tauhid dengan semangat keilmuan karena ilmu pengetahuan pada hakekatnya menjadi jembatan untuk mencapai kebenaran agama, yaitu tauhid. ${ }^{40}$

A.Malik Fadjar mengemukakan bahwa mutu masa depan UIN tidak bisa dilihat sekarang, tetapi perlu proses panjang. Berbagai pernyataan yang menaikkan kebencian dan bahkan hardikan akan gagalnya pendidikan selama ini perlu diluruskan. Karena berbicara masalah pendidikan adalah berbicara mengenai proses manusia dalam rentang waktu yang tidak instan, bukan sekadar dari fase ke satu fase, tapi proses yang berkesinambungan. ${ }^{41}$

Gagasan A.Malik Fadjar secara praksis diwarnai dengan nilai-nilai nasional dan global, karenanya yang perlu diperhatikan dalam konteks global adalah masalah multikulturalisme dalam berbagai aspek yang menempel kepadanya. Mengelola pendidikan mensyaratkan pemahaman multikulturalisme dengan meluaskan pergaulan ke berbagai kawasan negara, ideologi, organisasi, dan bahkan keyakinan (agama). Melalui hal ini peradaban global Islam akan terbentuk secara damai, ramah, dan menyejukkan.

Keberhasilan A.Malik Fadjar dalam pengembangan pendidikan, menurut Azyumardi Azra disebabkan karena A.Malik Fadjar selain melakukan pembaruan pendidikan Islam dan modernisasi juga berada dalam posisi-posisi yang strategis untuk mengambil kebijakan baik sebagai Dirjen Bagais, Menteri Agama, kemudian menjadi Menteri Pendidikan Nasional. Di sini bedanya A.Malik Fadjar dengan pemikir yang lain. Pemikir lain mungkin hanya sekedar pemikir, berwacana, merumuskan konsep, sementara A.Malik Fadjar lebih dari itu pernah jadi rektor UMM, UMS di mana A.Malik Fadjar sebagai penggerak perubahan itu. ${ }^{42}$

Oleh karena itu, STAIN/IAIN Menuju UIN yang digagas oleh A.Malik Fadjar dapat dipahami lebih berpijak pada konsep tauhid yang bermuara pada reintegrasi keilmuan baik ilmu-ilmu umum maupun agama, agar lebih kompetitif sebagai respon dari tantangan otonomisasi dan globalisasi. Dengan demikian sinergi keilmuan tersebut akan menciptakan atmosfir akademik yang kondusif sebagai cetak biru "Insan Indonesia Cerdas dan Kompetitif" yaitu lahirnya cendekia-cendekia Muslim yang berfikir kreatif, otentik, orisinal dan fungsional di masyarakat luas.

2001), h. 27

${ }^{40}$ Husni Rahim, Arah Baru Pendidikan Islam di Indonesia, (Jakarta: Logos Wacana Ilmu,

${ }^{41}$ A.Malik Fadjar, Holistika Pemikiran Pendidikan, h.40

${ }^{42}$ Muhammad Idris, Visi dan Praksis A.Malik Fadjar Dalam Pengembangan Pendidikan Islam, Disertsi SPS UIN Jakarta 2008. 
Jurnal Iqra' Vol.3. No.1, Januari - Juni 2009

\section{Kesimpulan}

Dikembangkannya IAIN/STAIN menuju UIN. Hal tersebut merupakan respons positif dan konstruktif terhadap tantangan dunia pendidikan yang menglobal. Dengan demikian dapat memproduk alumni-alumni yang memiliki competitive adventage, daya saing yang andal dan tangguh dalam menghadapi tantangan zaman. Perubahan IAIN menjadi UIN, dapat dilihat antara lain diresmikannya UIN Jakarta pada tanggal 08 Juni 2002, (Keppres Nomor 31 tahun 2002), UIN Sunan Kalijaga Yokyakarta (Keppres Nomor 50 Tahun 2004) dan UIN Malang (Keppres Nomor 50 Tahun 2004). menyusul kemudian UIN Pekan Baru Riau, UIN Makassar dan UIN Bandung. Semoga STAIN/ IAIN lainnya khususnya Manado dapat menyusul dengan mempersiapkan SDM yang memadai, sehingga dapat kempetitif dan marekatabel dalam mersepon tantangan zaman ke depan.

Wallahu a'llam bissawab

\section{Daftar Pustaka}

A.Palmer, Joy (ed), Fifty Major Thinkers on Education, London: Routledge, 2001.

Abdullah, Amin, Islamic Studies di Perguruan Tinggi; Pendekatan Integratif-Interkonnektif, Yogyakarta: Pustaka Pelajar, 2006.

Arief, Armai Reformulasi Pendidikan, Jakarta: CRSD Press, 2005.

Azra, Azyumardi, "Model Perubahan IAIN Alauddin Menjadi UIN; Sebuah Tawaran Berdasarkan Pengalaman UIN Jakarta" dalam Hadi D. Mapuna dkk. (Ed.), Dulu IAIN Kini UIN Alauddin, Makassar: Alauddin Press, 2005.

--------, Islam Subtantif: Agar Umat Tidak Jadi Buih, Bandung: Mizan, 2000.

Charles, Hoy. Et.al., Improving Quality in Education, New York: Falmer Press, 1999.

Fadjar, A. Malik, Reorientasi Pendidikan Islam, Jakarta: Fajar Dunia: 1999.

------------------, Holistika Pemikiran Pendidikan, Jakarta, PT Raja Grafindo, 2005.

, Kata Pengantar dalam Dodi Nandika, Pendidikan di Tengah Gelombang Perubahan, Jakarta: LP3ES, 2007.

Fazlurrahman, Islam, Chicago: The University of Chicago Press, 1979. 


\section{Muh. Idris - STAIN/IAIN Menuju UIN......}

Idris, Muhammad, Pemberdayaan Kualitas Umat Menuju Masyarakat Madani (Sebuah opsi memasuki masyarakat yang membebaskan) Tesis PPs. IAIN-Sekarang UIN Makassar 2006

,"Reformasi Pendidikan Islam dalam Sistem Pendidikan Nasional", Jurnal Iqra, No. 2. Tahun 2007.

Islam, Disertsi SPS UIN Jakarta 2008.

,Pola dasar pembaruan Dalam Pemikiran Pendidikan A. Malik Fadjar, dalam Jurnal Iqra' Vol. 6-Desember 2008.

Imam Tholkhah dan Ahmad Barizi, Membuka Jendela Pendidikan: Mengurai Akar Tradisi dan Integrasi Keilmuan Pendidikan Islam, h . 108

Jurnal Inovasi Pendidikan Tinggi Agama Islam, Perta, Vol. VII/No. 01/ 2004.

Kartanegara, Mulyadhi, Integrasi Ilmu dalam Perspektif Filsafat Islam, Jakarta: UIN Jakarta Press, 2003.

Kerr, Clark, The Uses of the University, New York: Harvard University Press, 1964.

M.Thomson, Merrit, The History of Education, New York: Barnes Noble INC Publisher, 1973.

Rahim, Husni, Arah Baru Pendidikan Islam di Indonesia, Jakarta: Logos Wacana Ilmu, 2001.

Suwito dan Suprapto, "IAIN Menjadi Universitas?", dalam Mimbar Agama dan Budaya, Vol. XVIII, No.2, 2001.

Suyanto, Dinamika Pendidikan Nasional,(Dalam Percaturan Dunia Global), Jakarta: PSAP Muhammadiyah, 2006.

T.S. Sodhi, A. Tex Book of Comparative Education Philosophy, Patterns and Problems of Nasional Systems, Delhi: Vikas Publishing, 1983.

Wilson, Bryan, Religion in Sociologi Perspective, New York: Oxpord University Press, 1982. 